\title{
A Persian Ghazal by Hafez and an Urdu Ghazal by Ghalib
}

\section{TRANSLATOR'S NOTE AND TEXT}

A ghazal is formally and metrically an integrated series of rhyming couplets, usually concerned with introspective states and frustrated desire; the final couplet almost invariably includes an apostrophe by the poet to him or herself. The genre dominates the classical canon of Arabic, Persian, and Urdu (sometimes combining two of these languages in a single ghazal). The introductory ghazal in Hafeze Shirazi's Diwan - that is, his complete collection of poems-begins and ends in Arabic half-lines; in between we have a collage of dark and lush Persian lines painting images of the poet's infinite loneliness and agony. As always, wine is both itself and far more than itself, and the Saqi, who pours the wine, to whom the poet speaks, holds out the hope of a still deeper and ever more painful intoxication. Hafez (my favorite poet) belongs to fourteenth-century Shiraz. Ghalib's Urdu ghazals, composed in eighteenth- and nineteenth-century Delhi, extend the Indo-Persian literary tradition to a South Asian mode haunted by the transient and idiosyncratic images of a poet who is mordant, witty, and fascinated by the infinite possibilities of refined despair. Ghazals are structured to explode any English translation that seeks to preserve the line-final refrain, which tends to sound mechanical outside of Persian-Urdu. I have attempted to capture something of the dense expressivity of Ghalib's refrain mere àge, "in front of, before, beside me, or in my eyes" by varying the adverbs and prepositions just a little.

GHAZAL 1 FROM HAFEZ'S DIWAN

Turn the cup, Saqi, and pour the wine, for love once seemed so easy.

Not anymore. ${ }^{1}(1)$ 
Morning: the soft breeze

tugs at a black curl.

Dark musk bursts in flame.

One drop of blood falls,

no more. (2)

At home in me, in the stations of love,

nothing is sure, when every moment

the bell cries out: "Pack up.

Stay no more.” (3)

Or the master speaks: "Pour wine

on the carpet and stain it dark.

This road belongs only to those

who know its lure." (4)

Black night, the violent waves, the whirlpools

of the sea. How can they know how I feel

who stand, unburdened,

on the shore? (5)

It all started when I tried to satisfy

myself. Then it turned bad.

They sing of us at parties. Secret

no more. (6)

If you seek that particular presence, Hafez:

don't disappear.

When you can't find what you're after,

release the world

once more. (7)

GHAZAL 208 FROM GHALIB'S BĀZĪCHAH-E AṬFĀL

A child's toy is this world, placed next to me.

Night and day parade without end-before me. (1)

Solomon's throne is my plaything,

that marvel of a Messiah, only one word-to me. (2)

No more than a name, this world has no shape I can see.

Nothing real, a wild thought moving-in me. (3)

In the dust I kick up, a desert hides.

The sea bows its head to the dust-before me. (4)

Don't ask what state I'm in after you.

Ask yourself what you're feeling when you're-around me. (5) 
You're right. I'm self-seeing, self-delighting. Why wouldn't I be?

An idol whose face is a mirror sits here-before me. (6)

Then look well to the words, redolent as roses.

if someone would place a goblet of wine-near me. (7)

I've gone through aversion, gone beyond envy.

So how could I ask that you not speak her name-before me? (8)

Faith holds me back, heresy pulls me forward,

the Ka'aba behind, a church-beyond me. (9)

I'm a lover. My work: to trick the one I love.

Laila maligns crazy Majnun-and then me. (10)

Be happy we don't die for nothing when we meet.

Say a prayer for the night you're not there-before me. (11)

Wave upon wave of this sea of blood sweeps me away.

See what comes next, getting closer and closer-to me. (12)

My hand won't move, but my eyes still breathe.

Leave goblet and bottle right here-for me. (13)

He's my colleague, my drinking partner. He shares my secret.

So why speak badly of Ghalib-before me? (14)

\section{THE LAYERED THOUGHT-WORLD OF THE GHAZAL}

\section{Rajeev Kinra (Near Reader)}

To observe that it is virtually impossible to reproduce the sonic effects and pulsating bundles of meaning characteristic of the Indo-Persian ghazal in English amounts to little more than a truism. This is especially so with a poet such as Hafez, the celebrated author of the first selection here, who is renowned not only for his elegant lyrical flourishes but also for his ability to manipulate language for intense (and often playfully ambiguous) semantic effect. And the challenge is only compounded in the case of the very first couplet when we realize-as all readers or hearers of the original text immediately do-that the poem's first line is actually in Arabic, not Persian: a rather jarring linguistic feature of the original that is impossible to reproduce in English: it must, almost by necessity, be erased entirely by the act of translating two source languages into one target.

And yet, despite these caveats, one may nevertheless contend rather confidently that just about anyone who has ever suffered in love and turned to drink for solace can relate to this opening couplet of Hafez's Diwan of collected verse. Love seemed so easy at first . . . and yet, inevitably, there were problems. The poet does not specify precisely what the problem is with his lover, however, remaining content 
with a certain productive ambiguity. In fact-and here we have our first glimpse into the layered thought-world of the ghazal as a form-he does not even convince us that he or she is a real person. Nor does he intend to; for the ghazal beloved is, to borrow a phrase, more than real-not just in the mundane sense captured by the English idiom "larger than life" (though that too is often true of the object of one's fervent romantic desire), but rather in the sense that he or she might actually be "He" or "She" (i.e., God), with whom the believer (especially the mystically inclined believer) so desperately desires metaphysical union, only to be frustrated by the cage of physical existence, trapped in a mundane material world that the mystic (and of course the poet) knows to be really just something like a dream.

In this reading, then, the poet is expressing not so much a crisis of romantic desire, but rather a crisis of spiritual faith - the difficulty of sustaining one's love and devotion to the Divine while inescapably mired in material existencewherein Belief takes the form of Love ( $i s h q$ ). But it is important to note that neither reading is the "correct" one. Rather, perhaps we should say that love, in the ghazal, is always a double entendre, never meaning just one thing ("real" worldly love) or another (real metaphysical Love), but often-one might even be bold enough to say always-available to be read both ways at once. Much of the pleasure, therefore, for both poets and connoisseurs, derives from this intentional hyperambiguity (what the Indo-Persian poets themselves refer to as ihamm), that the "meaning" of the couplet remains suspended in a state of play-always a both/ and rather than an either/or.

Where, exactly, is this drama unfolding? It would appear to be a tavern of some sort, which, as a refuge from the travails of life, love, and devotion (whether real or more than real), had already become a canonical topos in the Indo-Persian literary tradition long before Hafez came along, with the bartender (Saqi) as an associated stock character and the wine, the jug, and the cup as standard accoutrements. By revisiting this topos, and combining and recombining these conventional elements, or in some cases merely alluding to them, poets throughout the centuries could express any number of emotional and metaphysical states relating not only to love, loss, despair, and social alienation, but also to hope, anticipation, excitement, and the thrill of desire. Of course, Hafez's stature as one of the most (if not the most) towering figures of this lyrical tradition has always given this particular couplet-which is, after all, just one among countless others playing on the same trope(s) - a certain quotability, an almost proverbial or maybe aphoristic quality that is difficult to adequately explain to anyone unfamiliar with the literary cultures of the Persianate world. Indeed, one is hard pressed to find anything comparable in the Western literary tradition-perhaps some famous line of Shakespeare would come close, but even that doesn't feel quite right.

If the travails of L/love, generally speaking, are the subject of the first couplet, the next couplet moves us into the realm of a more specific problem: namely, the pain of separation from the $\mathrm{B} /$ beloved, one of the most common themes in ghazal 
poetry (as well as in the poetry and song of many other traditions). In this case, the lover is alone, pining for his absent beloved, but he is in luck (or is he?) 一the gentle morning breeze (sabā) has loosened the beloved's curly locks, and, like a kind messenger, brought him a whiff ( $b \bar{u}$; which can also mean "hope" or "expectation") of their perfumed scent. So far, so good. But what is happening in the second line? The musky scent of the beloved's hair, brought by the morning breeze, has caused his heart to fill with blood, thus only further inflaming his passionate agony. And we may detect an even further possible layer of meaning when we note that in the original Persian the term Hafez uses is actually dilhä: "hearts," plural. Does this multiplicity of hearts mean that our poet is not the only lover suffering the pangs of separation from this particular beloved? It would appear so-which would imply, too, that he has rivals for the beloved's affection, which can only increase his anxiety over not being with him/her.

But there's more. For if the breeze "tugs" at the beloved's twisty curls $(t \bar{a} b)$, unlocking their scent, it is their radiance (also $t \bar{a} b$, in a brilliant pun) that heats the hearts of the lovers, causing them to burst into flames. Indeed, as a number of commentators both classical and modern have noted, Hafez is playing here on a very complex physiological parallel between the musk sac (i.e., the source of the perfume) and the lover's heart. Typically, the musk used in creating perfume was harvested from a specific gland, a sac close to the musk deer's navel, which fills with blood when the deer's body becomes heated and eventually falls off, whereupon it can be collected and processed. The blood swelling in the hearts of longing lovers in the second line of the couplet thus mirrors the (implied) blood of the excited deer engorging the musk sac, which is itself a condition of possibility for the scent that perfumes the beloved's curly locks and in turn creates such heartsick agony all over town.

The pain of separation from the beloved is also a theme of the next couplet (3), albeit from a slightly different, one might say anticipatory, perspective. In this case the lover is actually with his beloved, but cannot bear the excruciating transitoriness of the encounter-the knowledge that this moment will soon pass, and they will inevitably be separated once again. It is a meditation on the ephemerality of worldly experiences, and the key image here is that of the caravan, which serves both as a literal setting for the verse and as a larger metaphor for life's journey. On the one hand, then, it can be read as a meditation on a specific rendezvous with a specific beloved; but we might also read the verse as a lament over the more general problem of the fleeting nature of life's pleasures, goals, and objectives. At an even more technical level, the word Hafez uses for "station" (manzil) here is also used in a Sufi context to refer to a stage along the mystic's path (tariqa) of spiritual awareness (' $i r f \bar{a} n)$ toward annihilation of the self $(f a n \bar{a})$. Thus, a mystical reading of the verse could be something like: how can I feel satisfied with achieving a new stage of awareness-i.e., closeness to the true Beloved, God-when I know that there is so far to go before I achieve true insight? 
Again, none of these is the "correct" reading, as such. Indeed, so much of the pleasure of ghazal poetry lies precisely in the jostling of these multiple interpretations - as well as other potential readings-bouncing off one another, always in a state of suspended animation.

If the setting for the previous couplet was the caravan (of life), here Hafez has returned us to the tavern with a striking imperative: "Stain the prayer carpet red with wine, if the master [of the tavern] tells you!" On the face of it, this instruction is about as blasphemous as it gets. Not only does it imply that one is drinking wine (which is technically forbidden, of course), but it adds the insouciant insult of telling the listener to be so sloppy as to spill wine not just anywhere, but on the prayer carpet. Whether it is because he has gotten so drunk that he just can't help himself, or because he is intentionally pouring the wine out onto the carpet is not immediately clear. Nor, for that matter, is it clear which would actually be worse from the standpoint of the moralist. But either way, here we have returned to the topos of wine drinking, not necessarily as a solace for love gone wrong as in the first couplet, but as a more general escape from social and religious orthodoxies.

The "master" invoked here is the so-called Magian elder ( $p \bar{i} r-i$ mughān), who appears as a conventional stock character in a lot of Persianate poetry representing Christian or sometimes Zoroastrian wine sellers or tavern keepers, since, as non-Muslims, they were allowed to engage in such professions without running afoul of injunctions against the sale and consumption of alcohol by Muslims. If we take the Magian elder in this sense, then the second line becomes a straightforward elaboration on the drunk and disorderly command issued in the first: "this road belongs only to those who know its [wine's] lure" - that is, hedonists. Such hedonists were also very common stock characters in the ghazal universe (and in Hafez's society, for that matter). But we should note, too, that in the original Persian the setting for this encounter between the "master" and the rowdy "traveler" (sālik) is not the road itself-although the "road" to decadence is certainly implied-but rather a particular station (manzil) along the way. Here manzil, in its worldly sense, refers to some kind of inn or tavern; and the "ways and customs" of the manzil are those of the drinking establishment-the "house rules", if you will, or, in Shulman's rendering, the "rules of the road." But while it is true that Christians and Zoroastrians were often associated with worldly wine selling in Persianate societies, they were also (especially the Zoroastrians) associated with ancient mysteries from the pre-Islamic era, and thus, with hidden esoteric knowledge. And the term sālik, although it does simply mean "traveler" in the mundane sense, was also very commonly used in Sufi parlance to refer to those who traveled the mystical path. The master's injunction to stain the prayer carpet with wine, in other words, however seemingly blasphemous, can also be read as an invitation to partake of the cosmic mysteries that are only available to those who are willing to transcend the usual orthodoxies in search of a higher truth, no matter the cost to their reputation or social standing. "This road," in other words, is not the path for 
any ordinary believer; it is only for those who are in on the secret, who "know its lure" of spiritual mysteries.

In the next couplet (5), we have suddenly left behind all the caravans, waystations, and taverns that have occupied our poet thus far, and been transported not just to another land, but in fact beyond the land altogether. It is the proverbial dark and stormy night, and we are, quite literally, lost at sea-suffering in fear of the churning waves and such frightful swirling eddies. Are we on a boat that is sinking? Or has the boat already gone down, and we are alone floating on the terrible ocean, just waiting until the waters rise up to finally claim us? The poet doesn't specify. But either way, what were we thinking? What on earth could have provoked us to embark on this foolhardy voyage in the first place? Such ambition, such vanity, such folly to think that we were strong enough to overcome nature's awesome power. And yet, at the same time, such vision and commitment-the sea may indeed claim us in the end, but at least we did not sit idly on the shore, wondering what could have been, or worse still, not even bothering to wonder about new horizons at all. They are the true fools, those "who stand, unburdened, on the shore" (sabuk-bārān-i sāhil-hā); how could they possibly know our true condition $(h \bar{a} l-i m \bar{a})$ ? It is a sentiment that can apply to any number of situations, most obviously the romantic ("how can those who play by the ordinary social conventions possibly understand the depths - and dangers - of my love for the unattainable beloved?") or even the spiritual ("how can those who play by the ordinary rules of religion possibly understand the enormous depths of my piety, which are forever threatening to drown me in oblivion"-which is not even necessarily a bad thing in the Sufi context!).

But if the fifth couplet explored the potential opportunity cost to any bold venture-it may wind up drowning you - in the next stanza Hafez suggests that there is also an opportunity cost to being the life of the party. The "party" in question is known in Persian as a mahfil, and it can refer variously to a literary salon, a musical assembly, a Sufi spiritual gathering, or some combination of the three. Thus the exact "secret" that the poet is worried about being revealed publicly is not immediately clear, but the verse hinges on the tension between the speaker's compulsive delight in whatever goes on in the mahfil (perhaps drinking, dancing, the recitation of risqué poetry, expressions of heterodox spirituality, etc.) and the moral hazards involved, not to mention the possibility —indeed the virtual inevitability-of his behavior becoming fodder for local gossip, and the ignominy that will surely follow when it is "secret no more."

Though the couplets we have discussed thus far have all been multilayered and complex in their own ways, none is arguably as cryptic as the final verse of the ghazal. Indeed, even expert commentators have disagreed for centuries as to its exact meaning and figurative intent. But perhaps the first thing we should note here, for the general reader, is that from a linguistic standpoint it is a perfect symmetrical bookend to the first couplet, in that the first line is in Persian while the 
second is in Arabic-an important part of the texture of the original that is inevitably smoothed over, as it were, by any attempt to translate it. At a deeper level, though, the difficulty with this couplet is not so much that we can't figure out what the poet is saying - the syntax is perfectly clear-but that it is not entirely clear what he means.

The question before us is what, exactly, Hafez means by the duality of "presence" and "disappearance" to which this verse calls our attention. Whose presence does the poet seek that is currently (at least by implication) absent from him? Is it the beloved, to whom he must continue to present himself in order to have any hope of success, despite his/her indifference? Is it a king or some other patron? Is it God? Is it the art of poetry itself, as the noted modern scholar Julie Meissami has argued? Is it some other "particular presence," as Shulman has translated it here with just the right touch of elegant ambiguity?

In the end, the exact meaning remains an elusive mystery. But it is precisely Hafez's ability to create such mysterious yet enthralling poetic effects that prompted a later poet, the celebrated 'Abd al-Rahman Jami (d. 1492), to famously dub him the "tongue of the unseen" (lisān al-ghaib) - using a term, perhaps not coincidentally, that is etymologically related to the very word for invisibility/absence ( $g h \bar{a} i b)$ that Hafez employs in this last couplet. And over the centuries, Hafez's reputation as the "translator of secrets" (tarjumān al-asrär) has hardly diminished. Indeed, it is exactly this feature of his poetry that has led people across the Persianate world to use his dīwān for the purposes of divination in times of trouble, distress, or worry. This was true in Persopone India as well, but interestingly enough, in the nineteenth century another figure would emerge from the world of classical Urdu literature whose work would also come to be used on occasion for such popular bibliomancy: Ghalib, the poet to whom we turn next.

Ghalib. For our next selection, we move forward in time by roughly half a millennium, and also move into an entirely different language, now commonly known as Urdu, which began to replace Persian as the preferred literary medium of the urbane courtly intelligentsia in Mughal northern India over the course of the eighteenth and nineteenth centuries. The poet, Mirza Asadullah Khan "Ghalib" (17971869), was one of the towering figures of this relatively new classical Urdu tradition, though he was also a prolific Persian poet as well. In purely literary historical terms, then, Ghalib was an important transitional figure: a man born into the elite society of the late Mughal courtly world, and thus still deeply (some might even say stubbornly) imprinted by the established traditions of classical Indo-Persian language, literature, culture, and manners, but also one whose own career and fame in many ways embodied the crest of the new Hindi-Urdu vernacular wave from which Indian Persian language and literature would arguably never recover. He began his life as the scion of an elite family of Mughal aristocrats, and ended it as a subject of Queen Victoria, even going so far as to pen lofty panegyrics to 
her in hopes of securing the patronage of the British government. He was a man of awesome literary ego (indeed arrogance, in the eyes of more than a few of his contemporaries), who expected a certain amount of deference from most he interacted with; and yet also a man of tremendous wit, and one of the more colorful bons vivants of nineteenth-century Delhi-a habitual tippler, gambler (for which he was jailed on at least one occasion), ladies' man (reportedly), and general man about town. He had some notoriously acerbic feuds with poetic rivals, and yet, especially in his letters, could also display remarkable warmth, empathy, affection, and kindness, especially for the downtrodden and down on their luck. He was, needless to say, one of the most fascinating and contradictory figures in all of nineteenth-century Indian cultural life.

A great many of these personality traits are reflected in the ghazal translated here, which Ghalib composed for the royal Mughal salon in Delhi, in May 1853. Overall, it is twice as long (fourteen couplets) as the selection from Hafez, and one of the things that stand out immediately upon reading the original Urdu is the striking emphasis on the self-on the "I" (or rather "my") of the poetic voice.

For a ghazal poet to adopt such a first-person speaking voice is not unusual, per se, but to do so this consistently in a single poem, and with such repeated emphasis, is relatively rare. Another somewhat quirky feature of this ghazal, beyond its intense projection of the poet's own self (or some version of it), is that it begins with what appears to be intended as a four-couplet "set"- -something that is also rather unusual in the ghazal tradition, in which each couplet is typically treated as an independent poetic utterance. The ghazal's unity, in fact, insofar as it has any, is in most cases purely formal: the poem must conform to the correct meter and rhyme throughout, but beyond that there are few imaginative constraints on each individual couplet. This is why, as we saw with Hafez, it can be quite difficult to write about a whole ghazal without breaking it up into its constituent parts, its sequence of various "poems two lines long," as the noted Urdu literary scholar Frances Pritchett once described them (or, if you prefer, "orient pearls at random strung," as Sir William Jones famously put it all the way back in 1771). Ghalib, however, sometimes had a sly way of using his ghazals to explore variations on a theme, and this is a perfect example.

One way to read this opening set of four couplets is as an expression of Ghalib's personal sense of confidence and grandeur. But there are other possibilities, the most obvious being a mystical reading: these things, these trappings of material life are all just a show ( $\operatorname{tam} \bar{a} s h \bar{a})$, not the ultimate Reality. If we take this approach, then we are suddenly dealing less with the megalomaniacal musings of a selfabsorbed aristocrat than with a deeper meditation on the ephemerality of worldly existence as such. Yet another possibility is to think of the speaker neither as Ghalib himself, nor as Ghalib adopting the persona of a visionary Sufi mystic, but rather as Ghalib in his capacity as a poet, that is, as a poet-creator. One could even read these verses as a meditation on aging, and the ennui that comes with too much 
experience of the world. The speaker is so weary of life that he is able to discern the essential flimsiness of material existence in a way that younger, more optimistic, more passionate, and less jaded souls cannot yet appreciate. Ghalib himself was nearly sixty years old when this ghazal was written, so it is certainly not out of the question. Again, one of the great delights of the ghazal as a form-which is also precisely what can make them so agonizing to translate and explicate-is that we are not required to choose which of these is the "correct" reading of these verses. They can all linger in a state of play, and remain so, each potential interpretation more or less equally valid all at once.

All of the grand pronouncements of the first four couplets suddenly give way, however, to the far more common poet-lover's lament over his abasement at the hands of a cruel beloved in the fifth couplet. In fact, in addition to this rather abrupt thematic shift, for the next three couplets the mode of address adopted by the speaker has shifted as well, from general statements about the world as he sees it to second-person statements addressed directly to a specific interlocutor. "Don't even ask about my condition," he complains at the beginning of the fifth couplet-ironically enough, after spending the previous four couplets boasting bombastically about exactly that!- "now that you have left me behind." He is speaking, presumably, to the beloved who has jilted him; and given the ghazal universe's conventional emphasis on-indeed, celebration of - the poet-lover's subjugation to the capricious and cruel whims of the beloved, one might have expected the second line to delve further into his tortured state. But in this case Ghalib chooses defiance instead, telling the beloved, essentially, to take a good look at him-/herself first and see what the effect of his/her cruelty has been on his/her own self. Thematically, then, the verse crackles with a somewhat unexpected insolence on the part of the poet-lover; instead of wallowing in his sorrow as we might expect, he has turned the tables on the cruel beloved and implied that $\mathrm{s} / \mathrm{he}$ is the one who should truly be sorry.

The next couplet also addresses the beloved directly, but here Ghalib dispenses with the unexpectedly confrontational attitude of the previous verse in favor of a lighter, more playful, and even admiring touch. The first line has the speaker, seemingly defensive, strangely confessing to what might ordinarily be seen as the rather narcissistic character flaws of "self-seeing" and "self-delighting." But then in the second line we learn that the speaker is not infatuated with his own beauty, but rather his reflection in the beloved's face, which is so radiant, so shiny, that it acts like a mirror. Mesmerized by his own image reflected in that "mirror-faced idol" (but-i a ${ }^{\prime} i n a-\operatorname{sim} \bar{a}$ ), he appears arrogant, vain, narcissistic, and preening, but he is in fact merely overawed by its reflective power.

In the next couplet (7), however, it is the poet's interlocutor who will do the seeing. "Then look well," the speaker insists in the first line, "to the words, redolent as roses." Here Ghalib appears to be referencing his own poetry (literally, his "rose-scattering style of expression"; andāz-i gul-afshānī-yi guftār), telling his 
interlocutor-perhaps a sympathetic bartender, or perhaps his rival poet(s) in the mahfil - that while they may have been impressed with what they had heard so far (whether Ghalib's own verse or that of some other poet), there is much better yet to come, poems of such style and grace that they will be like flowers spread far and wide, as they are recited and repeated all over town by lovers of good poetry. But there is just one thing lacking: a goblet of wine to fuel his inspiration.

As we have seen, the ghazal universe is one that is populated by numerous stock characters such as the poet-lover, the beloved, the bartender, the annoying moralist, the friendly advisor, and the romantic or literary rival, as well as multiple stock topoi associated with them such as the tavern, the garden, the literary gathering, the house of worship, and the bazaar. These and other archetypal characters and physical settings are well known to connoisseurs of the tradition, and one of the things this allows poets to do is to say a lot with an extreme economy of actual words. They are able to suggest the presence of certain types of characters in certain situations without having to be explicit, and as we have seen, good poets like Hafez and Ghalib could even exploit this power of suggestion to toy with our expectations and generate intense, and often multiple, meaning(s) - a process that Indo-Persian literary critics refer to as "meaning creation" (ma'nī-äfrinin) or sometimes "theme creation" (mażmūn-äfrin̄i), depending on the exact features of the verse.

Thus, in three of the next four couplets, Ghalib explores a range of emotive states related to the travails of romantic love, from sorrow and regret to irrational exuberance. There is a seemingly jilted lover ('áshiq) who is trying to get over the one-time object of his affections, and can't bear even to hear his/her name (8). This is followed by an apparently scheming 'āshiq who invokes the classic doomed archetypal lovers Laila and Majnun to proclaim, somewhat mysteriously, that he makes it his business "to trick the one I love" (10) - a strange sort of admission in a literary universe that typically (and often literally) idolizes the beloved, and celebrates the 'ashiq's willingness, even eagerness, to endure incredible suffering in her absence and cruel indignities in her presence. ${ }^{2}$ Finally, there is an encounter in which the 'ashiq's longed-for union with the beloved feels so intense that he literally dies of happiness-and yet, ironically enough, it is in that very moment of blissful self-sacrifice, so often compared in Indo-Persian lyrics to the moth burning up in the irresistible flame, that this particular lover recalls with nostalgia the longing he felt on an earlier night of separation (shab-i hijrān) from the beloved, when he so desperately wanted to die of grief, even as he is actually dying of joy (11). The latter is one of the great "agony of separation" couplets in Ghalib's oeuvre, one that also harkens back to the topos explored in Hafez (in which the poet-lover cannot even truly enjoy the moment of union with the beloved, for all he can think of is the fact that they will soon inevitably be separated once again; couplet 3).

There is also a long tradition in Indo-Persian literature of the ghazal being used to express dissent, particularly against religious orthodoxy. The flouting of social 
norms and Qur'anic injunctions such as the prohibition against wine, for instance, was probably the most routine form of such dissident expression. Indeed, as we saw earlier with Hafez (4), these paeans to inebriation could sometimes intensify into something more, even verging on outright blasphemy, albeit usually modulated with a mystical sensibility that made such poetry not so much irreligious, per se, but rather a kind of orthogonal piety that was thought to transcend "mere" orthodoxy. What we have in Ghalib (9), however, is a classic example of yet another variation on the theme: not a protest against orthodoxy as such-at least not directly-but rather a cri de coeur bemoaning the individual believer's crisis of faith, or existential angst more generally. Ambivalent about faith (immān), and drawn by the allure of infidelity ( $k u f r$ ), Ghalib here nevertheless expresses an arguably even greater existential dilemma than Hafez's drunken injunction to simply abandon conventional piety and "stain the prayer carpet red with wine" - namely, that he cannot be so cavalier because a part of him still believes, even if he has doubts, and even if he is enticed by the potential truth of other religious traditions.

The theme of existential unease continues in the next couplet (12), which evokes a dread of "wave upon wave" threatening to drown the poet that is similar to Hafez (5), only this time it is even worse-a "sea of blood," with no end in sight. The speaker's only hope is that the storm abates, but how can he be sure that it will? Indeed, it might even get worse. And thus, we are left to wonder about the poor man's fate. But we are also left to wonder: what exactly is this "sea of blood"? Some commentators have interpreted it historically, perhaps as a reference to political turmoil of the nineteenth century generally, or even more specifically to the bloody reprisals that the British visited upon Delhi following the mutiny of 1857. In fact, Ghalib himself even cited the verse in a post-1857 letter to a friend about the devastation he witnessed. And yet, we know for a fact that this particular ghazal was composed before the rebellion, in May 1853 (something we rarely know with such specificity). Another possibility is that the "sea of blood" is actually a deluge of the poet-lover's own tears, which are "bloody" from his grief-stricken bloodshot eyes. Ghalib has a number of other famous couplets in which such "tears of blood" are central to the imagery, as well as a whole host of other verses that play on the trope of the solitary lover crying torrents of tears in grief over his separation from the beloved. The "sea of blood" could even be a metaphor for worldly existence as such - a reading that could be corroborated by other verses by Ghalib that draw on similar imagery, such as the famous one in which he laments: "existence has drowned me, so what matter if I never existed?"

These kinds of intertextual resonances are probably of more interest to connoisseurs than the general reader, but I flag them nevertheless, because they are such an important part of the economy of literary and emotive pleasure associated with the ghazal as a form. Another is the performance setting in which such verses were often recited, sung, and heard, which encouraged poets to tease the audience by extending the ambiguity of the couplet's meaning, and deferring as 
long as possible the utterance of the key word or phrase that will, in turn, disclose the overall couplet's real meaning(s) and theme(s). The penultimate couplet of this ghazal (13) is a perfect illustration. After the end of the first line, we have no idea what is actually going on. The speaker can barely move, but he still has enough life left that "[his] eyes still breathe." Is he dying? Perhaps! The second line begins with an injunction to "leave" something be, without immediately specifying its object, which creates a suspense that does not carry over to the translation, but might be exploited by anyone singing or reciting the couplet to heighten the effect even further. Is it the shovel they will use to bury him, now that he has died for love? Is it his own body, which, despite all appearances, he protests still has life left in it (at least in the eyes)? Is he trying to be left alone to die a peaceful death and "go gentle into that good night," or is he rather desperate, à la Dylan Thomas, to "rage, rage against the dying of the light"? We still don't know! Until, at last, we hear the key words "goblet and bottle" (säghar-o-minnā) and it all snaps resoundingly, amusingly, into focus: he's merely been dead drunk all along.

Finally, another feature of the ghazal that poets often exploited for effect is the traditional expectation that the last couplet of the poem (known as the maqta') would include some reference to the poet's own pen name, or takhallus. This is why, in Hafez (7), the verse is addressed directly to someone named "Hafez," while the actual speaker of the couplet remains ambiguous - it could be Hafez admonishing himself, or it could be Hafez the poet assuming the guise of some other person in order to offer advice to an imaginary version of himself named Hafez. And here in Ghalib (12) we encounter a similar dynamic. The speaker, it would appear, is not Ghalib himself but someone speaking about Ghalib to an unidentified third party, one who is apparently speaking ill of the poet. "He is my colleague, my drinking partner," and "he shares my secret," the speaker protests; "so why do you speak badly of Ghalib," and that too right in front of me?

To whom is this complaint addressed? One immediate possibility is that it the beloved-that is, Ghalib's beloved, with whom the speaker is conversing. This reading is supported nicely by the wording of line two, which, in the original Urdu, is almost identical to that of the tenth couplet in which the speaker was either complaining or boasting that Laila was bad-mouthing Majnun, depending on how we interpret it. Perhaps it is one of Ghalib's literary rivals denigrating his poetic talents, or some other prominent person around town denouncing his dodgy morals. Perhaps he is speaking to some religious scold - the irritating orthodox mullah also being a common stock character of the ghazal universe-and chiding the latter for being so uptight. Or maybe, just maybe, the speaker actually is Ghalib, and he has somehow found himself in a situation where people are bad-mouthing him, or his poetry, or his character, or whatever the case may be, without knowing that they are speaking to the man himself-and this is his cheeky way of telling them off-by continuing the pretense that he is someone else, some other disinterested observer coming to his own defense, but deep down reveling in the irony as if to 
say: "how funny that you would stand there insulting my good friend Ghalib, in front of me of all people!"- and letting all of us in on the secret.

THE GHAZAL OF WHAT'S MORE THAN REAL

Peter Cole (Far Reader)

FOR D. S.

And now words reach us as Persian meets Urdu, making ours real, and then some, like David's do

in an English he's always leaving behind and returning to, as it happens, like dew

on grass or a vine's blue grapes-even a glass left out in a garden his poets imbue with powers. Still, he'd be the first to tell youit's a mirage. Meaning's mortgage. Maybe true.

True and not true. Glistening, as we see ita kind of beloved. Something desire drew, drawing us too. Again lines are leading him beyond himself, and soon he's bidding adieu to ease, with ease, in every way. It pleases him, who'll share his secrets, as though they were new, so they will be. So leaning and learning meet along a mind's mirror, coupling there, a clue.

Residue ... of a slow knowing - as fog stops the brown mountain: I imagine, therefore you are. Therefore, imagine, so that I might be with you, wandering friend, when these debts come due. 